\title{
Bilateral slipped capital femoral epiphysis as first manifestation of primary hyperparathyroidism in a 15-year-old boy
}

Obustronne złuszczenie głowy kości udowej jako pierwsza manifestacja pierwotnej nadczynności przytarczyc u 15-letniego chłopca

\author{
1'Dorota Roztoczyńska, ${ }^{1}$ Małgorzata Wójcik, ${ }^{2}$ Aleksander Konturek, ${ }^{3}$ Anna Nogieć, \\ ${ }^{4}$ Alicja Hubalewska-Dydejczyk, ${ }^{1,5}$ Jerzy B. Starzyk
}

${ }^{1}$ Department of Pediatric and Adolescent Endocrinology, University Children's Hospital of Krakow, Poland 2Department of Endocrinological Surgery, Third Chair of General Surgery, Medical Faculty, Jagiellonian University Medical College, Krakow, Poland ${ }^{3}$ Laboratory of Genetic Studies, Clinical Department of Endocrinology, University Hospital, Krakow, Poland ${ }^{4}$ Chair and Department of Endocrinology, Faculty of Medicine, Jagiellonian University Medical College, Krakow, Poland ${ }^{5}$ Department of Pediatric and Adolescent Endocrinology, Chair of Pediatrics, Pediatric Institute, Jagiellonian University Medical College, Krakow, Poland

\begin{abstract}
Primary hyperparathyroidism (PHP) in children is a rare condition and has a very dynamic course with nonspecific symptoms, what complicates the diagnosis and delays PHP treatment.

Case presentation: A 15-year-old boy was admitted to the Orthopedic Ward with the diagnosis of juvenile bilateral slipped capital femoral epiphysis and valgus deformities. Gait disturbances, limb pains and valgus knee deformities, polyuria, polydipsia and weight loss, have been increasing for 8 months. Despite the hypercalcemia found in laboratory tests and bone destruction demonstrated in computed tomography of the hips, orthopedic correction was performed. In histopathological examination -brown bone tumors. The PTH concentration was determined (PTH - 589.1 pg/ml; (N: 10-60) and the child was referred to the Department of Pediatric Endocrinology, where severe hypercalcemia (Ca-4.07 mmol/l, N: 2.2-2.84) and hypophosphatemia ( $\mathrm{P}-0.68 \mathrm{mmol} / \mathrm{l} ; \mathrm{N}: 0.95-1.75)$ and adenoma of the left lower parathyroid gland was diagnosed. Forced diuresis, loop diuretics and pamidronic acid were used to obtain normocalcemia. The complications of hypercalcemia were excluded; diagnostic management excluding multiple endocrine neoplasia type 1 and 2a (MEN 1 and MEN 2A) syndrome were performed. The child was referred to the Department of Endocrinological Surgery, where the adenoma of the left inferior parathyroid gland was resected.

Conclusions: 1) Patients with PHP should be diagnosed of the condition based on clinical symptoms. In patients with specific symptoms, it is necessary to determine serum Ca levels, especially prior to the surgical procedures. 2) In each case of PHP, determinations should be made of blood PTH, Ca and P and detection of MEN 1 and MEN 2A syndromes. 3) Patients with hyperparathyroidism require management of multiorgan complications of hypercalcemia. 4) Following surgical treatment of parathyroid adenoma, longterm endocrinological follow-up is necessary.
\end{abstract}

Key words:

parathyroid glands, adenoma, parathyroidectomy.

\section{Streszczenie}

Pierwotna nadczynność przytarczyc (primary hyperparathyroidism - PHP) u dzieci jest rzadkim schorzeniem o burzliwym przebiegu i nietypowych objawach, co utrudnia rozpoznanie i opóźnia leczenie.

Prezentacja przypadku: Chłopiec, lat 15, został przyjęty na Oddział Ortopedii z rozpoznaniem obustronnego złuszczenia głowy kości udowej oraz koślawości kończyn dolnych. Zaburzenia chodu, bóle i deformacje kończyn obserwowano od 5 miesięcy, polidypsję, poliurię i utratę masy ciała od 8 miesięcy. Mimo hiperkalcemii stwierdzonej w badaniach laboratoryjnych oraz destrukcji kości, którą wykazała tomografia komputerowa bioder, wykonano zabieg ortopedyczny. W badaniu histopatologicznym stwierdzono guzy brunatne kości. Stężenie PTH - 589.1 pg/ml; (N: 10-60). Pacjenta skierowano na Oddział Endokrynologii Dziecięcej, gdzie 
stwierdzono ciężką hiperkalcemię (Ca c. - 4.07 mmol/l; N: 2.2-2.84), hipofosfatemię (P - 0.68 mmol/l; N: 0.95-1.75). Rozpoznano gruczolaka lewej, dolnej przytarczycy. Po zastosowaniu forsowanej diurezy, diuretyków pętlowych i kwasu pamidronowego uzyskano normokalcemię. Wykluczono powikłania hiperkalcemii oraz zespoły MEN 1 i MEN 2A. Na Oddziale Chirurgii Endokrynologicznej usunięto gruczolaka przytarczyc.

Wnioski: 1) Pacjenci z PHP powinni być diagnozowani na podstawie typowych objawów klinicznych, a oznaczenie stężenia Ca przed zabiegami ortopedycznymi jest konieczne. 2) W każdym przypadku PHP należy oznaczyć Ca, P, PTH w surowicy oraz wykluczyć zespoły MEN 1 i MEN 2A. 3) Pacjenci z PHP wymagają diagnostyki wielonarządowych powikłań hiperkalcemii. 4) Po operacji gruczolaka przytarczyc niezbędna jest długoterminowa opieka endokrynologiczna.

\section{Key words:}

przytarczyce, gruczolak, parathyroidektomia.

\section{Introduction}

Primary hyperparathyroidism (PHP) is a condition that is exceptionally rare in developmental age, its incidence in children is $2-5 / 100,000$ [1-5]. Hyperparathyroidism is a complex of clinical symptoms where the predominating element is hypercalcemia resulting from excessive PTH production [6]. Primary hyperparathyroidism may be an isolated condition or a component of various syndromes, e.g. MEN 1, 2A and 4; it also may be sporadic or familial. Development of PHP has been associated with numerous germinal and somatic mutation of genes such as MEN1, RET, CDKN1B, PRAD1, HRPT2, HRPT3 [7-9]. In the majority of cases, PHP is a consequence of adenoma involving one parathyroid gland, only in $3 \%$ of cases it results from multiple adenomas $[3,6]$. Clinical symptoms of PHP usually involve the skeletal, urinary, gastrointestinal, neuromuscular, and cardio-vascular system; abnormalities are also detected in the organ of vision $[3,4,6,10]$. In adults, as many as $80 \%$ of patients with PHP are asymptomatic, while in children the condition has a very dynamic course, oftentimes with nonspecific symptoms, what renders the diagnosis markedly difficult and delays PHP treatment [5]

\section{Case presentation}

A 15-year-old boy was admitted to the Orthopedic Ward, University Children's Hospital of Krakow, with the diagnosis of juvenile bilateral slipped capital femoral epiphysis and valgus deformities involving both lower extremities, especially on the left side. Gait disturbances, limb pains and valgus knee deformities, have been increasing for 5 months, polyuria, polydipsia and weight loss have been increasing 8 months. After 6 months the boy was consulted by an orthopedic surgeon. At the same time, tests performed in his local health care facility demonstrated hypercalcemia (Ca-3.15 N: 2.10-2.55), which was not taken into consideration in diagnostic management of bone lesions. Despite those contraindications, the surgical procedure has been planned. CT of the hips demonstrated bone destruction with predominating bilateral lytic lesions, numerous osteolytic foci varying in size and involving the proximal ends of the femurs. The patient presented with a single lytic focus in the inferior-anterior zone of the left iliac, $22 \times 12 \times 25 \mathrm{~mm}$ in size, joint space narrowing involving both hip joints, soft tissue thickening and exu- dation in the hip joints (Fig. 1). Bone scintiscan with ${ }^{99} \mathrm{mTc}$-Methyl diphosphonate (Tc $\left.{ }^{99} \mathrm{~m}-\mathrm{MDP}\right)$ was performed and demonstrated an enhanced uptake in the long bone epiphyses, ribs and flat bones. After 8 months the boy underwent nailing in situ of the slipped capital right femoral epiphysis, subcapital osteotomy of the left femoral bone and osteotomy of the distal left femoral epiphysis aiming at removing valgus-associated lesions. Histopathology of the material collected from the femoral neck demonstrated ambiguous lesions that might have corresponded to giant cell reparative granuloma, brown tumor and giant cell tumor. Following determination of the PTH level - $589.1 \mathrm{pg} / \mathrm{ml}$; ( $\mathrm{N}: 10-60 \mathrm{pg} / \mathrm{ml}$ ), the boy was referred to the Endocrinology Outpatient Department, University Children's Hospital of Cracow. The boy walked on crutches; apart from bone pain, he reported poorer appetite, constipation, polyuria, polydipsia and body weight loss of approximately $10 \mathrm{~kg}$ in the past year (Fig. 2). His family history was negative with respect to PHP and multiple endocrine neoplasia (MEN) syndromes. Physical examination demonstrated good general condition, his height was 169, $2 \mathrm{~cm}$ (-0,35 z-score standard WHO growth charts), weight $53 \mathrm{~kg}$, $10 \%$ body mass deficit, body mass index $18,77 \mathrm{~kg} / \mathrm{m}^{2},(-0.10$ Z-score standard WHO growth charts), heart rate of $120 / \mathrm{min}$, arterial pressure of $140 / 80 \mathrm{~mm} \mathrm{Hg}$, acne lesions on the face, surgical scars in the iliac region and left thigh, puberty at Tanner stage V (Fig. 3). Out-patient tests showed hypercalcemia (Ca $4.07 \mathrm{mmol} / \mathrm{l}, \mathrm{N}: 2.2-2.84)$ and hypophosphatemia ( $\mathrm{P}-0.68$ $\mathrm{mmol} / \mathrm{l} ; \mathrm{N}:$ 0.95-1.75). Ultrasound detected a hyperechogenic area measuring $1.5 \times 2.05 \mathrm{~cm}$ in the inferior left thyroid pole

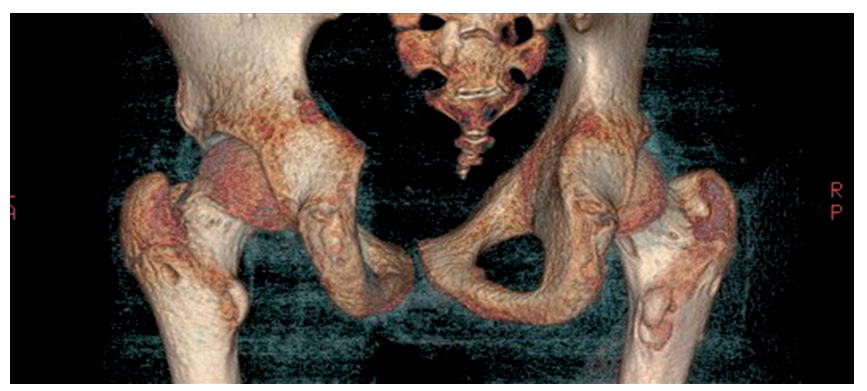

Figure 1. 3D rendering of the CT scan, a single lytic focus in the inferior-anterior zone of the left iliac, $22 \times 12 \times 25 \mathrm{~mm}$ in size, joint space narrowing involving both hip joints, soft tissue thickening and exudation in the hip joints 
Body mass

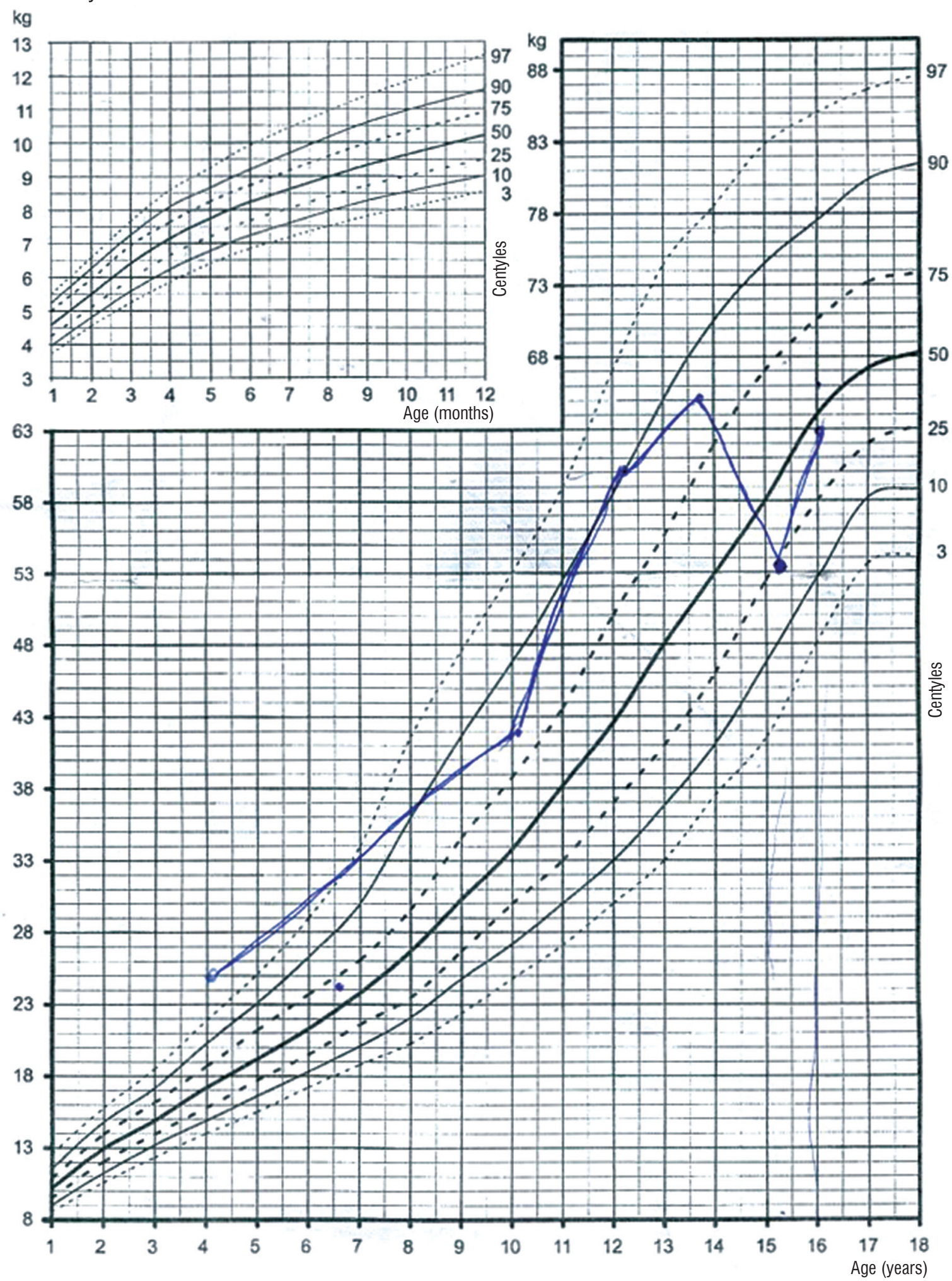

Figure 2. Changes of the body mass 


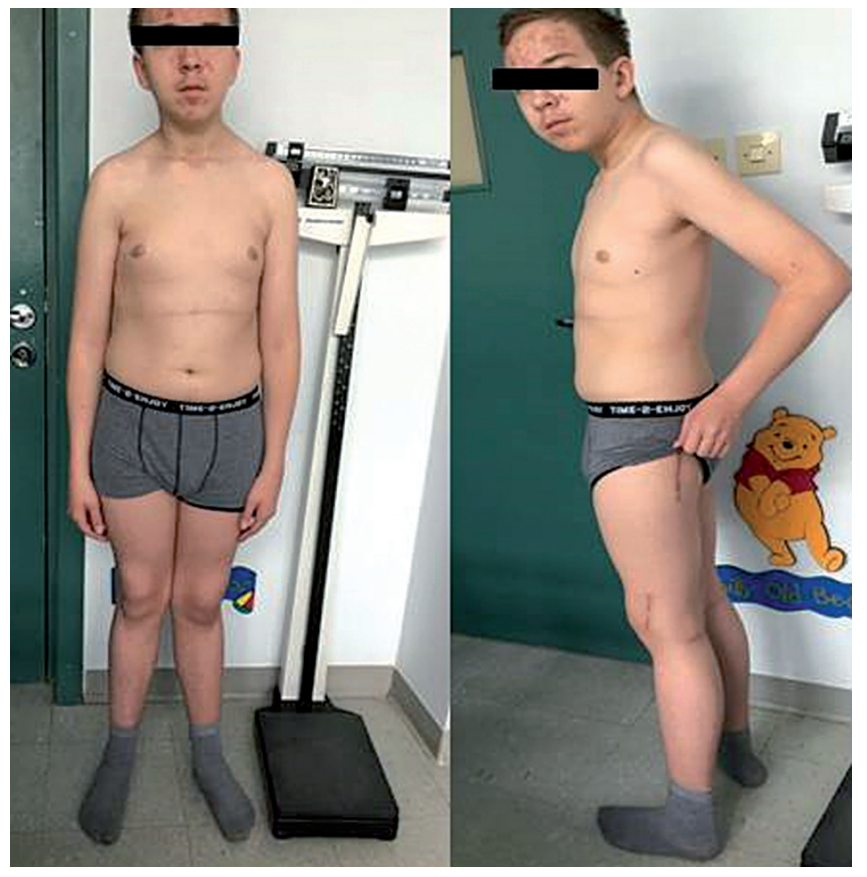

Figure 3. 15-year old patient with parathyroid adenoma after surgery due to bilateral slipped capital femoral epyphysis

(Fig. 4). Spine densitometry (DEXA Hologic) showed decreased bone mineral density (z-Score - 1.9 SD), while scintiscan of the neck SPECT/CT (Technetium ${ }^{99 m}$ Tc sestamibi) demonstrated an enhanced uptake in the inferior left parathyroid gland. Due to severe hypercalcemia, the boy was urgently admitted to the Endocrinology Ward, University Children's Hospital of Cracow. His general condition was good. On admission, he presented with an elevated calcium value ( $\mathrm{Ca}-4.00 \mathrm{mmol} / \mathrm{l})$, hypophosphatemia ( $P$ - $0.84 \mathrm{mmol} / \mathrm{l})$, hypomagnesemia $(\mathrm{Mg}-0.59 \mathrm{mmol} / \mathrm{l}$; $\mathrm{N}: 0.6-0.95)$ and vitamin $\mathrm{D}_{3}$ deficit $\left(25(\mathrm{OH}) \mathrm{D}_{3}: 7.2 \mathrm{ng} / \mathrm{ml}(\mathrm{N}\right.$ : 20-60). His TRP $=88 \%$ was normal (N: 85-95\%), 24-hour urine showed marked hypercalciuria ( $\mathrm{Ca}-0.32 \mathrm{mmol} / \mathrm{kg} / \mathrm{d}$ ), abdominal ultrasound was normal. ECG demonstrated shortened ST and QTC $=0.34$ intervals typical for hypercalcemia. No pathological lesions were detected by computed tomography of the head and hypothalamus and ophthalmologic examinations.

Initially, forced diuresis and loop diuretics were employed, yet the expected reduction of calcemia did not occur. Subsequently, pamidronic acid was added (two intravenous doses of $30 \mathrm{mg}$ ) and the effect was good. During pamidronic acid infusions, the patient presented transient flu-like symptoms with fever and leucopenia. Phosphate deficits were treated with oral phosphate mixture; magnesium and vitamin $D_{3}$ supplementation was also introduced, resulting in a gradual normalization of serum electrolytes after 8 days of treatment.

Diagnostic tests to exclude MEN 1 and MEN 2A syndromes (Multiple Endocrine Neoplasia) were performed: serum A chromogranin, calcitonin and gastrin levels and 24-hour urine
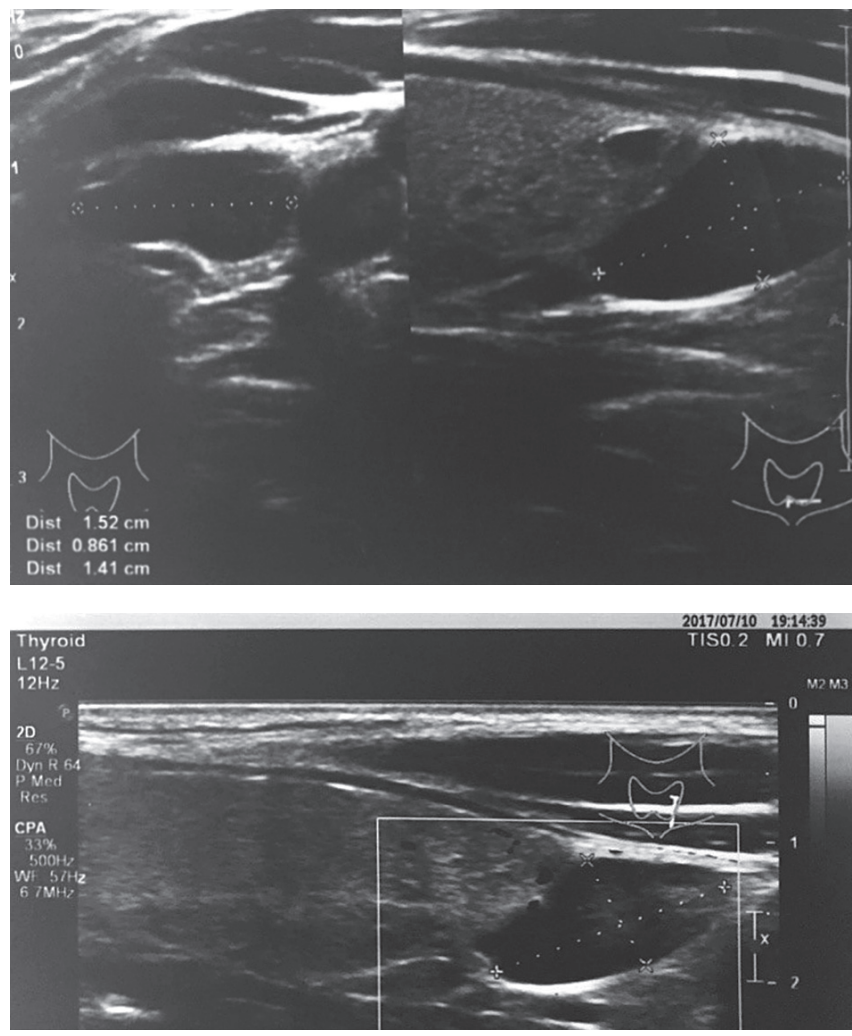

Figure 4. Ultrasound examination of the neck - hyperechogenic area measuring $1.5 \times 2.05 \mathrm{~cm}$ in the inferior left thyroid pole

catecholamine metabolite values were normal. The thyroidal, adrenal and gonadal axis function was within the norm, similarly as prolactin concentration levels. Gastrological diagnostic management including endoscopy ruled out abnormalities that might have corresponded to complications of hyperparathyroidism or MEN syndrome. The analysis of chromosome 11q13 region excluded mutations of the MEN1 gene.

The child was referred to the Department of Endocrinological Surgery, Third Chair of Surgery, Jagiellonian University Medical College, where the left inferior parathyroid gland was resected. Histopathology confirmed the presence of an adenoma. Complete normalization of calcium, phosphates and PTH concentration values was achieved. The child continues to be treated as an outpatient: his serum electrolytes are tested; phosphate supplementation has been gradually reduced and he continues to take vitamin $D$ and calcium preparations. The boy moves efficiently, without crutches, and experiences no pain.

\section{Discussion}

In view of its low incidence and non-specific course, establishing the diagnosis of PHP in children may be markedly delayed or even not taken into consideration in therapeutic man- 
agement. The interval between the onset of symptoms and the diagnosis is usually 2 years. In this period, permanent organ lesions may develop, such as osteoporosis, kidney damage, peptic ulcers, pancreatitis or arterial hypertension that may persist in spite of resolving the cause of hypercalcemia [3]. Numerous authors emphasize a considerable number of erroneous diagnoses and cases of treating abnormalities that are a consequence of undiagnosed hyperparathyroidism [3, 11]. In the above described boy, the pronouncedly elevated calcium level, loss of body mass and dynamics of bone lesions suggested the diagnosis of PHP rather than juvenile bilateral slipped capital femoral epiphysis. Hypercalcemia, polyuria and polydipsia persisting for approximately 9 months (from the onset of symptoms to treatment initiation) did not result in other permanent organ lesions apart from bone complications. Another dangerous consequence of delayed diagnosis of hyperparathyroidism may be hypercalcemic crisis that is a directly life-threatening condition. Described for the first time by Dawson and Struthers in 1923, it is characterized by severe hypercalcemia ( $\mathrm{Ca}>14 \mathrm{mg} / \mathrm{dl}$ or $>3.5 \mathrm{mmol} / \mathrm{l}$ ) leading to symptoms of multiorgan failure [8]. Prior to the era of bisphosphonates, calcimimetics or plasmapheresis, hypercalcemic storm was an indication for surgical resection of parathyroid glands within 72 hours, with perioperative mortality rates of $14 \%$. At present, therapeutic methods allow for normalizing plasma electrolytes before surgery and the incidence of hypercalcemic storm and surgical complications has decreased to 2.8\%. In addition, imaging studies (parathyroid scintiscan) and intraoperative PTH monitoring have increased the effectiveness of surgical treatment of parathyroid adenomas up to 92\% [2]. Postoperatively, such patients, especially individuals with bone complications, require endocrinological treatment with calcium and vitamin $\mathrm{D}$ preparations due to the risk of hypocalcemia associated with the hungry bone syndrome [8]. Concentration

\section{References}

1. Bauman BD, Evasovich M, Louiselle A, et al. An occult ectopic parathyroid adenoma in a pediatric patient: a case report and management algorithm. J Pediatr Endocrinol Metab 2017; 30: 995-999. doi: 10.1515/jpem-2017-0077

2. Dey S, Beawarwala A, Gupta S, et al. Protean Presentations of Parathyroid Adenoma in Childhood. J Indian Assoc Pediatr Surg 2017; 22: 40-42. doi: 10.4103/0971-9261.194620

3. Krzewska A, Sieniawska J, Kapczuk I, et al. Nawracająca kamica dróg moczowych jako objaw gruczolaka przytarczyc u 16-letniej pacjentki. Endokrynol Pediatr 2015; 14: 57-62.

4. Menon P, Dayal D, Rao SG, et al. Childhood parathyroid adenoma: a rare but important cause of nephrolithiasis. J Pediatr Endocrinol Metab 2016; 29: 853-856. doi: 10.1515/jpem-2015-0369

5. Soyer T, Karnak I, Tuncel M, et al. Results of intraoperative gamma probe survey and frozen section in surgical treatment of parathyroid adenoma in children. J Pediatr Surg 2016; 51: 1492-1495. doi: 10.1016/j.jpedsurg.2016.04.007 values of calcium, phosphates, PTH and $25(\mathrm{OH}) \mathrm{D}_{3}$ should be monitored, similarly as renal function and bone density. In the pediatric population, almost one-half of cases of PHP has a genetic background. Diffuse parathyroid hyperplasia with underlying MEN 1 and MEN 2 syndromes and non-MEN associated familial hyperparathyroidism is much more common in children as compared to adults [3]. In case of multiple adenomas, especially in children, one should take into consideration genetic background of the lesions and an increased risk of relapses $[9,11,12]$. For this reason, despite negative family history, the presented patient underwent hormonal and genetic diagnostic tests aiming at ruling out MEN; follow-up determinations of $\mathrm{Ca}$, $\mathrm{P}$ and $\mathrm{PTH}$ values are planned in his parents.

\section{Conclusions}

1. Patients with parathyroid adenoma should be diagnosed/ suspected of the condition based on clinical symptoms of hypercalcemia, such as loss of appetite, nausea, constipation, stomachache, polydipsia, polyuria, and most of all based on bone lesions. In patients with non-specific symptoms, it is necessary to determine serum Ca levels, especially prior to the planned surgical procedures.

2. In each case of PHP, determinations should be made of blood PTH, Ca and P and the patient should undergo complete diagnostic hormonal and genetic management aiming at detection of MEN 1 and MEN 2A syndromes.

3. Patients with hyperparathyroidism require diagnostic management of multiorgan complications of hypercalcemia.

4. Following surgical treatment of parathyroid adenoma, longterm endocrinological follow-up is necessary in view of the risk of disorders of calcium phosphate metabolism, as well as the risk of hyperparathyroidism relapse.

6. Wójcik M, Starzyk J. Nadczynność przytarczyc. W: Kawalec W, Grenda R, Ziółkowska H. Wyd. Lek. PZWL, Warszawa 2015; 879-881.

7. Davidson JT, Lam CG, McGee RB, et al. Parathyroid Cancer in the Pediatric Patient. Pediatr Hematol Oncol 2016; 38: 32-37. doi: 10.1097/MPH.0000000000000443

8. Serrano-Gonzalez M, Shay S, Austin J, et al. A germline mutation of HRPT2/CDC73 (70 G > T) in an adolescent female with parathyroid carcinoma: first case report and a review of the literature. J Pediatr Endocrinol Metab 2016; 29: 1005-1012. doi: 10.1515/jpem-2016-0109

9. Thakker RV. Genetics of parathyroid tumours. J Inter Med 2016; 280: 574-583. doi: 10.1016/j.beem.2010.07.003

10. Misiorowski W. Postępy w rozpoznawaniu i leczeniu pierwotnej nadczynności przytarczyc. Post N Med 2008; 3: 184-190.

11. Krysiak R, Bartecka A, Okopień B. Rzadkie zaburzenia funkcji przytarczyc i działania receptorowego parathormonu. Przegl Lek 2014; 7: 136-147.

12. Davies JH. A Practical Approach to Problems of Hypercalcemia. In: Allgrowe J, Shaw NJ (eds). Calcium and Bone Disorders in Children and Adolescents; Endocr Dev Basel, Karger 2009; 16: 93-114. 